MAJÓ Zoltán

\title{
AZ ELEKTRONIKUS HUMÁNERŐFORRÁS- MENEDZSMENT ÉS A HR-OUTSOURCING ÉRTELMEZÉSI ÉS KAPCSOLATI RENDSZERE
}

Több cikk jelent meg az elmúlt években e-HRM témában, melyekben technológiaszemléletú megközelítés uralkodott. Vagyis az e-HRM - vagy a virtuális HR - lényegében mint a HR-tevékenység elektronikus, webalapú innovatív támogatása szerepelt a szakkifejezések között. Furcsa módon, amíg az e-HRM megjelenésével kapcsolatban a 90-es évek végén és az ezredfordulón az elemzók és a szakértók pont a HR megerôsödését, stratégiai szemléletú HR-tevékenység elớtérbe kerülését várták, mára kiderült, hogy ennek éppen ellenkezôjje jellemezte az elmúlt pár év üzleti folyamatait. Virágzik a HR-outsourcing, azaz HR-tevékenység kiszervezése. Ez paradox módon pont az e-HRM-alkalmazásoknak köszönhetố, hiszen az infokommunikációs technikák és az elektronizált HR-rendszerek lehetőséget teremtettek a HR-outsourcingra. A cikk bemutatja, hogy az e-HRM fogalmában az ,e” hangsúlya eltolódik. Nem az ,elektronikus” HRM-mel kell foglalkoznunk, hanem humáneróforrás-menedzsmenttel egy „e" világban. Az írás elemzi a Bondarouk (University of Twente, Hollandia) által vezetett kutatócsoport e-HRM-definíciós kísérletét, és annak Harvard modellbe való adaptációját, és végül, de nem utolsósorban modellszerú magyarázatot ad a HR-outsourcingra.

Kulcsszavak: elektronikus humáneróforrás-menedzsment (e-HRM), HR-outsourcing, humán erốforrás információs rendszer (HRIS), infokommunikációs technológia, információmenedzsment

„akkor fogom beadni a lemondásom, ha már a fizetésemelésemról is e-mailben értesitenek, és ezt nem személyesen közli velem a fónököm” (anekdota, $P \& G$ )

Több cikk jelent meg az elmúlt években az elektronikus humánerőforrás-menedzsment (e-HEM, e-HRM) témában, magyar és angol nyelvú folyóiratokban, melyek hangvételét jól szemlélteti az alábbi idézet:

„Az e-HEM mintha a személyzetisek álmainak megvalósulását ígérné: megszabadítja óket az unalmas és idôt rabló adminisztratív feladatoktól, több idôt hagyva a humáneróforrás-menedzsment stratégiai feladataira és az emberi kapcsolatokra..." (BME OMIKK HRM 2003/6.)

A szúkebb értelemben formálódó szakma, akadémiai szinten, 2006 ôszén tartotta elsố európai konferenciáját, Hollandiában. A konferencián közel ötven oktató és kutató vett részt, jórészt Franciaországból, Németországból, Hollandiából és Angliából, de érkeztek ameri- kai és argentin vendégek is, és Kelet-Európát Magyarország „képviselte” a tudományos rendezvényen.

A plenáris ülésen elóadást tartó Dr. David Lepak (Rutgers University, USA) az e-HRM-tevékenységet boncolgatva rámutatott: véleménye szerint történetét tekintve egy technológia szemléletú megközelítés uralkodott eddig az e-HRM-fogalommal kapcsolatban, ami átértékelésre szorul. Az e-HRM, vagy a virtuális HR lényegében mint a HR-tevékenységek web-alapú innovatív támogatása szerepelt eddig kifejezéseink között. Az üzleti élet szereplői, a tanácsadók és a kutatók is a hagyományos HR-funkciók (pl. toborzás, fejlesztés, képzés) információtechnológián alapuló kiterjesztésének előnyeirôl (Miller, 2003; Enyedi, 2003), annak költséghatékonyságáról (Tóthné, 2002), a HR-munkában bekövetkező technológiai változásokról (Korponay, 2002; Ruta, 2005) és a Humán Erőforrás Információs Rendszerek (HRIS), megnövekedett jelentőségéról (Ball, 2001; Kovach et al.1, 2002) beszéltek eddig. 
Ez a megközelítés Lepak véleménye szerint - legalábbis Amerikában - már múlt időbe tehetô. Az e-HRM fogalmában az „e” hangsúlya eltolódik. Nem az „elektronikus" HRM-mel kell foglalkoznunk, hanem a humánerőforrás-menedzsmenttel egy „e” világban. Lepak szerint a környezeti változás - ami a globalizációval és a hálózatosodással jellemezhető leginkább - alapkérdések vizsgálatát veti fel ismét: hogy mit nyújt(hat) a HR a munkatársaknak, mit ad(hat) a HR a vállalatoknak, és végül, de nem utolsósorban, mi lesz a személyzeti osztályokkal, HR-igazgatóságokkal?

A konferencia egyik „legforróbb” témája a humáneróforrás menedzsment osztályok sorsa ebben az „e-világban". Vajon a humáneróforrás-menedzsment kiszervezése (HR-outsourcing) általános tendenciává válik? Megszúnhetnek a HR-osztályok? A konferencia résztvevői abban egyetértettek, hogy furcsa módon, amíg a tudásmenedzselés megjelenésével kapcsolatban a 90-es évek végén az elemzók és a szakértốk pont a HR megerósödését, stratégiai szemléletú HR-tevékenység előtérbe kerülését várták, mára kiderült, ennek éppen ellenkezője jellemezte az elmúlt pár év üzleti folyamatait. Virágzik a HR-outsourcing, azaz a HR-tevékenység kiszervezése.

A felvetett kérdések aktualitását jól mutatja, hogy az elmúlt évben több könyv is foglalkozott a HR jövőjével (ebból kettó magyar nyelven is megjelent: HR a XXI. században, illetve a HR jövóje: az emberieróforrásmenedzsment perspektívái). Mindkét könyv nagyléptékú változásokra számít a HR-munkában. Stan Davis amerikai szerző a HR-funkció fejlődése kapcsán a munkaügyi kapcsolatok osztályát, majd a személyzeti osztályt és végül a humáneróforrás-menedzsment igazgatóságokat egy fejlődési (evolúciós) láncként szemléli, melyben szerinte a harmadik fázis végéhez értünk, de a következő „láncszemet” még nem látjuk, nevét sem tudjuk. Azt azonban érzékeljük, hogy az információs társadalmi hatások a munka világát átalakítják, az internet modernizálja a HR-munkát, és a „tudásmunkás” menedzselése új kihívások elé állítja a HR-t (Davis, 2004).

Cikkemben az e-HRM és a HRoutsourcing fogalomrendszerével foglalkozom, mely véleményem szerint az infokommunikációs technológia (IKT) változásokon keresztül elvezethet a fenti kérdések egyik kiváltó okához. Rámutatok, hogy a HRoutsourcing és az e-HRM fogalomrendszere közös vonásokat mutat, így paradox módon a bevezetô idézetben szereplő,,személyzetisek álma" a HR vállalaton belüli funkciójának átalakulásához, illetve térvesztéséhez vezethet. Módszertani szempontból ennek a magyarázó faktornak a vizsgálatát három lépésre bontottam: az e-HRM fogalmi rendszerének tisztázására (1), a HR-outsourcing és az e-HRM logikai kapcsolatának bemutatására (2), és esettanulmányokkal történő megalapozására (3). Kiinduló hipotézisem szerint az infokommunikációs technikák adaptálása, az e-HRM rendszer bevezetése egyben lehetôséget teremt a HR-tevékenységek kiszervezésére.

\section{Az e-HRM fogalma}

Az e-HRM-fogalom átfogó vizsgálatára, elméleti modell felállítására és gyakorlati megalapozására Dr. Tatyana Bondarouk és kutatócsoportja tett kísérletet három évvel ezelőtt egy egyetemi kutatási program keretében, (Bondarouk - Looise - Ruel, 2004) Hollandiában. A szerzôk részletesen vizsgálták a Lepak által is felvetett fogalmi problémát. Arra jutottak, hogy a technológiai szemlélet szúkítóleg hat az e-HRM megértésére, mivel az nem ad választ arra, hogy milyen módon kapcsolódik az e-HRM a HR-munkához. A vizsgálódásuk eredményeképpen a szerzók az e-HRM fogalmát a következố módon határozták meg:

Aze-HRMa humáneróforrás-stratégia, -(irány)elvek és -eljárások implementációja a szervezetben internetes technológiákra alapozva.

Bondarouk és társai hangsúlyozzák, hogy értelmezésük szerint az implementáción van a hangsúly. Másképp fogalmazva: az e-HRM nem más, mint a HR-tevékenység múködésbe hozatala szervezeti szinten, az

1. ábra

\section{Az e-HRM fogalmi rendszere}

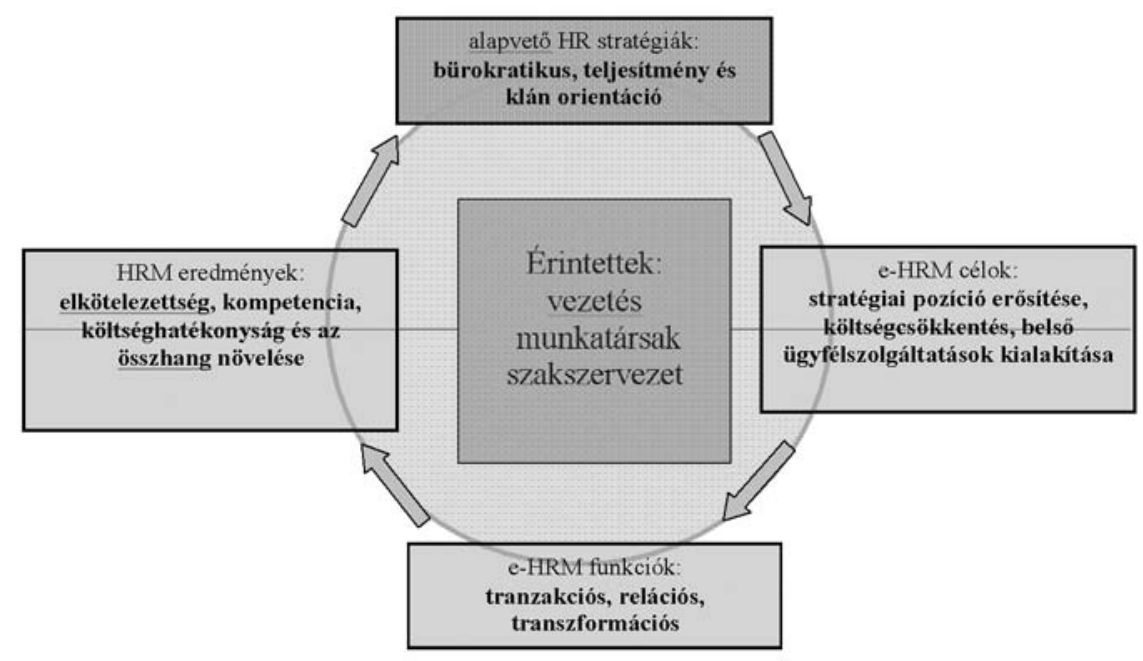

Forrás: Bondarouk, Looise, Ruel, e-HRM: Innovation or Irritation? 
infokommunikációs technikák segítségével. A fogalom rendszerét az 1. ábra szemlélteti, melyet a szerzók a Harvard modellre építették (Beer et al., 1984).

Az 1. ábra jól szemlélteti, hogy a szerzók az e-HRM fogalmát olyan ciklikus rendszerként képzelik, mely négy pillérre épül: az e-HRM hatókörét meghatározza a HR-stratégia, melyhez a kitúzött e-HRM-célok mentén az e-HRM-funkciókon keresztül ,vezet” az eredményekig. Az elért eredmények ismeretében a ciklus kezdődik elölról. Ennek a fogalmi rendszernek az egyes elemeit érdemes egyesével is számba venni a fogalom elmélyítése érdekében.

\section{HR-stratégiák és HR-orientációk: a HRM helyzete a vállalaton belül}

Minden szervezet rendelkezik valamilyen implicit vagy explicit HR-stratégiával, a munkatársakra, a munkavégzésre vonatkozó irányelvekkel, hiszen minden menedzsmentdöntés magában hordoz emberierőforrásvonatkozást is. A szerzók a Harvard modell kiinduló rendszerét adaptálják (Beer et al., 1984), mely szerint háromféle irányelv követése jellemzó a szervezetekre:

- bürokratikus orientáció,

- teljesítmény orientáció,

- klánorientáció.

Beer eredeti könyvében részletesen foglalkozik ezzel a három irányelvvel. A bürokratikus orientációjú szervezetek a szabályozottság és az ellenôrzés magas szintjét építik ki, jellemzô rájuk a hierarchia. A szervezetben a belépố munkatársak általában egy alacsony beosztási szinten kezdhetnek, és haladhatnak előre a „ranglétrán” a szervezet belső szabályai szerint. Ezen szervezetek általában munkakör-értékelés alapú rendszereket fejlesztenek és üzemeltetnek (ilyenek napjainkban például az egyetemek). A teljesítményorientációjú (piacorientált) szervezetek jellemző módon az egyéni teljesítményt állítják a fókuszba: a munkaerópiacon a legjobb készségekkel és tapasztalattal rendelkező munkavállalókat keresik, az egyéni eredmények ösztönzésére alkalmas módon alakítják ki rendszereiket. Ennek kapcsán teljesítményarányos módszereket és rendszereket preferálnak (ilyenek napjainkban például a biztositótársaságok). A klánorientációjú szervezetek jellemző módon a csoportokra helyezik a hangsúlyt. A munkavállaló amint bekerül egy ilyen típusú szervezetbe, első lépés, hogy elsajátítsa (általában vállalati képzés és tréningek keretében) a speciális vállalati kultúrát, szaktudást, és azonosuljon a vállalati értékekkel. A munkaszervezésre jellemző a csapatmunka és a konzultáció (ilyenek napjainkban például a globális jelenléttel rendelkezó tanácsadó cégek).
A HR-orientációkkal kapcsolatban - mely az egyedi vállalati stratégiák alapja - már Beer is utal arra, hogy a munkakultúrák szempontjából az európai szervezetekre a bürokratikus orientáció, az amerikaiakra a teljesítményorientáció, míg az ázsiai vállalatokra klánorientáció a legjellemzóbb. Beer munkájában azt is megemlíti, hogy egy szervezeten belül akár mindhárom orientáció is előfordulhat.

\section{e-HRM-célok - miért döntenek a szervezetek az e-HRM bevezetése mellett?}

Ezen alapvetô HR-orientációk mellett különbözô célok vezérelhetik a döntéshozókat, amikor az e-HRM bevezetése mellett döntenek. Szakirodalmi adatokra támaszkodva a célok és okok között három releváns tényezốt talált a holland kutatócsoport. Ezek a következók:

1. a humánerőforrás-menedzsment stratégiai orientációjának növelése,

2. költségcsökkentés/eredményesség növelése,

3. HR-szolgáltatások színvonalának emelése, a munkatársak ügyfélközpontú kezelése.

A szerzók szerint minden e-HRM-törekvés „célkeresztjében” ez áll: legyen szó a toborzás webalapú támogatásáról, a munkaerô képzését támogató e-learning keretrendszerról, vagy akár önkiszolgáló cafeteria rendszert magában foglaló HR-portál szolgáltatás bevezetéséról.

\section{e-HRM-fajták - alapvetó HR-funkciók}

A holland kutatócsoport szerint az e-HRM nem egy önálló tématerület a humáneróforrás-menedzsmentben, mint a toborzás, a kiválasztás vagy a teljesítmény-értékelés, hanem ahogy a fogalommeghatározásban is utaltak rá: egy lehetőség a HR-stratégia megvalósítására. Ennek ismeretében Wright és Dyer, valamint Lepak és Snell munkáira támaszkodva (Lepak - Snell, 1998; Wright - Dyer 2000; Lepak, 2005), funkcionálisan a HR-munka három szintjét különböztették meg, mely egyben az e-HRM fajtáit is meghatározza. Ezek sorrendben a következók:

- HR-tranzakciós funkciók,

- HR-relációs funkciók,

- HR-transzformációs funkciók.

Ez a csoportosítás megközelítésében újszerúnek mondható. Érdekessége a HR-tevékenységek tárgya szerinti csoportosítás. A mindennapos HR-munka egyrészt az ügyvitel fenntartására, a munkaügyi és személyes adatok kezelésére irányul (HR-tranzakciók: szerződések, kinevezések, bérszámfejtés stb). Másrészt a HR-munka része a munkatársakkal mint individuu- 
mokkal való foglalkozás: azok megszerzése, megtartása, fejlesztése, és ehhez a különböző HR-szolgáltatások kialakítása, üzemeltetése (HR-relációk: toborzás, kiválasztás, tréningek, teljesítményértékelés stb.). Harmadrészt a HR-munka tárgya maga a munkaszervezet: a HR részt vesz a vállalati kultúra kialakításában, annak megváltoztatásában, a tudásmenedzsment kiépítésében és stratégiai megújításában (HR-transzformációk: kultúraváltás, érdekegyeztetés stb.). Megjegyzendő, hogy Wright és Dyer már eredeti cikkében is hangsúlyozza: a múltban a HR-osztályok energiáját 65-75\%-ban a tranzakciók, 15-30\%-ban a relációk és csak 5-15\%ban a transzformációk kezelése kötötte le (Wright - Dyer, 2000). Az e-HRM, tágabb értelemben az e-business, ezeken az arányokon módosíthat, akár a tranzakciók kezelésének teljes outsorcingjával. Így a HR nagyobb figyelmet szentelhet az értéknövelt szolgáltatások kialakítására és a stratégiaalkotásra.

\section{e-HRM-eredmények - HRM-kimenetek}

A szerzók definíciós kísérletéból adódóan az eHRM-eredményeknek és a HRM-eredményeknek azonosnak kell lenniük, hiszen akkor sikeres az e-HRMtevékenység, ha implementálni tudja a HR-stratégiát a munkaszervezetbe. Ennek következménye, hogy a modellben az eredmények szempontjából a HRM-kimeneteket kell számba vennünk, vizsgálnunk. Az alapvetố kimeneteket a HRM-, így az e-HRM-tevékenység kapcsán már a Harvard modell is rögzíti, ami négy kimenetet jelöl meg (4C):

- az elkötelezettség (commitment),

- a kompetencia (alkalmasság, competence),

- a költséghatékonyság (cost effectiveness),

- az összhang növelése (congruence).

A szerzók adaptálják a Harvard modellt, mely arra épít, hogy ezen kimenetek minden stakeholder (menedzserek, tulajdonosok, munkavállalók stb.) számára relevánsak és fontosak. Az elkötelezettség nemcsak a vállalat iránti elkötelezettséget (lojalitás) és a jobb munkateljesítményt takarja, hanem az egyéni kiválóság megbecsülését és a munkatársak iránti tiszteletet is. Az alkalmasság növelése azt jelenti, hogy a megfelelő képességú és tudású emberek a megfelelő idôben és a megfelelő helyen legyenek a szervezetben: a „munkavégzés" a szervezet számára hasznos és eredményes, a munkavállaló számára pedig „kihívás” legyen. A költséghatékonyság növelése azt jelenti, hogy a juttatások, a személyzeti költségek minden szereplő számára elfogadhatóak legyenek. Az összhang pedig azt takarja, hogy az egyéni, a csoportos, a szervezeti és közösségi szinten a munkatevékenység összhangja magas szinten valósuljon meg. Ha ennek a szintje alacsony, akkor sok idôt, energiát emészt fel a stressz kezelése, az együttmúködés és a bizalom megteremtése és a közös szándékok tisztázása.

Az így megalkotott fogalmi keretrendszert összevetve a technológiai szemléletû e-HRM-megközelítéssel, mely a HR-infokommunikációs technológiákkal, főleg internettel történő támogatására épült, összefoglalóan elmondhatjuk, hogy az valóban szúkítóleg hatott az e-HRM értelmezésére. Bondarouk és szerzôtársai az e-HRM-tevékenységet egy négytényezôs ciklikus folyamatba ágyazták, mely kiindulva a szervezet HRstratégiájából, az irányelvek implementációjaként értelmezi az e-HRM-tevékenységet. A fogalom kapcsán lefektették az e-HRM speciális céljait, tárgyát és eredménykritériumait is. Az e-HRM a költségcsökkentés, a HR szolgáltatások színvonalának emelése, a stratégiai szemlélet erôsítése mentén a HR-tevékenységek internetes megújításán keresztül (HR-adminisztráció, toborzás, kiválasztás, tudásmenedzsment stb.) hat a munkaerő hatékonyságával és eredményességével kapcsolatos kimenetekre (elkötelezettség, kompetencia stb.).

\section{A HR-outsourcing és az e-HRM logikai kapcsolata}

\section{A HR-outsourcing értelmezése}

A humáneróforrás-kiszervezés (human resource outsourcing - HRO) jelenségvilága a XXI. századhoz köthető. Greer és szerzőtársai 1999-ben megfogalmazták ezzel kapcsolatban, hogy a HR-területen belül döntési helyzet alakult ki. Kérdésfelvetésük arra irányult, hogy a HR-osztály szempontjából mi az, amit a jövớben magunk akarunk csinálni, és mi az, amit érdemes megvásárolni (Greer et all., 1999). Két évvel késốbb Keebler írásában rámutat, hogy az outsourcing nem új keletú jelenség a HR világában, az már fél évszázados múltra tekint vissza. Az újdonság abban keresendő, hogy a taktikai outsourcingot felváltotta a funkcionális, illetve a totális outsourcing, amikor már nem egy-egy feladatot, hanem egy funkciót, vagy egy komplex ügymenetet szerveznek ki, és a menedzsment részéról a modern információtechnológiáknak köszönhetően folyamatosan kontrollálható (Keebler, 2001). Hasonló következtetésre jut Poór is (Poór, 2001), aki szerint az internet, illetve az e-business következménye, hogy új típusú szervezeti formák és menedzselési megoldások kerülnek ,szemünk elé" az emberi erôforrás területén. Ez az outsourcing tendencia egyesek szerint a periférikus üzleti folyamatoktól elindulva ,egyre közelebb kerül” a magtevékenységekhez (Szabó -Hámori, 2006). 
A közelmúlt üzleti tendenciáit jól szemlélteti Watsonwyat-et globális trendkutatási eredménye. Ezek szerint a vizsgálatban szereplő cégek 53\%-a valamely HR funkció kiszervezése mellett döntött az elmúlt években, de a „totális” HR-outsourcing nem jellemző a vezetố nagyvállalatokra sem (Watsonwyat-et, 2005). A felmérés rámutatott, hogy a kihelyezés egyre több vállalatnál napirenden van, és a szervezetek egyfajta mixét tervezik a belsố és külső HR-szolgáltatásoknak. Ezt a tendenciát mutatja a Cedar-jelentés is (Cedar, 2006), mely a globális felmérésében a HR-outsourcing meghatározó területeit az előtakarékosság és nyugdíjazás, a juttatások és a bérszámfejtés területén azonosította, de nem mutatkozik igény a válaszok tükrében a munkaerótervezés, munkakör-elemzés, vagy teljesítmény-értékelés területén a kiszervezésre. A felmérésében szereplő vállalatok ezeket olyan kompetenciákként azonosították, melyek szervezeten belüli megoldást (in-house) igényelnek. Poór 2006-ban a fejlett nyugati országok és a magyar HR-gyakorlat összehasonlításában (Poór, 2006) kitér a HR-outsourcingra is. Bemutatja, hogy a folyamatok hasonlók, de eltéró intenzitással bírnak. Amíg a fejlett nyugati országok HR-gyakorlatában átlagosan 1-5, addig nálunk csak 1-2 tevékenységet szerveznek ki.

\section{A HR-outsourcing indokai}

A bemutatott outsourcing-tendenciáik értelmezése a kiszervezés indokainak feltárásával magyarázható leginkább. Ennek kapcsán többen rámutatnak, hogy a költségmegtakarítás az egyik alapvetô kiváltó ok (Roberts, 2001; Turnbull, 2002), de a Delta Airlines, a Pepsico vagy az AT\&T kiszervezési tapasztalatai ennél sokkal messzebbre vezetnek (Henneman, 2005): előtérbe kerül a mérhetôség, a HR-rendszerek megtérülésének vizsgálata és a külsố szakértelem bevonása (Cooke - Shen - Mcbride, 2005). Graddick magyarul is olvasható tanulmányában hasonlóképpen vélekedik: írásában kifejti, hogy a HR-outsourcingtól jelentős költségmegtakarítást remél a cégvezetés, és a kiszervezésnek köszönhetôen a HR valószínúleg jobban tud majd koncentrálni a stratégiai jelentőségú területekre (Graddick, 2005). Graddick emellett írásában rögzíti, hogy a belsố HR-nek virtuális erőforrásokat kell megtanulnia kezelni, legyen az a szervezeten belül vagy kívül, hiszen a kiszervezett tevékenység ugyanúgy a HR része marad, csak a feladat megoldásáért mostantól piaci szolgáltatók versenyeznek (ami eddig költség volt, most üzleti lehetőséggé válik). Emellett a HR-stratégiák és az eHR közötti kapcsolatok vizsgálata kapcsán Reddington felveti, hogy a virtualizáció és a HR-outsourcing között potenciális kapcsolat húzódik (Reddington - Martin, 2006), mely a hasonló célrendszerben keresendő.

\section{Aze-HRM}

\section{és a HR-outsourcing kapcsolata}

Amennyiben a HRO indokait és az e-HRM fogalmi rendszerében előzóekben lefektetett célokat összevetjük, érdekes logikai kapcsolatot fedezhetünk fel a két terület között, amit az 1. táblázat szemléltet:

1. táblázatt

\section{Az e-HRM-célok és a HRO-indokok} egybevágósága

\begin{tabular}{|l|c|}
\hline $\begin{array}{c}\text { e-HRM-célok Bondarouk } \\
\text { és szerző́társai szerint (2004) }\end{array}$ & $\begin{array}{c}\text { HRO-indokok Graddick } \\
\text { szerint (2005) }\end{array}$ \\
\hline $\begin{array}{l}\text { 1. A humáneróforrás } \\
\text { menedzsment } \\
\text { stratégiai orientációjának } \\
\text { növelése }\end{array}$ & $\begin{array}{c}\text { A A HR jobban tud majd } \\
\text { koncentrálni a stratégiai } \\
\text { jellegú tevékenységekre }\end{array}$ \\
\hline $\begin{array}{l}\text { 2. Költségcsökkentés/ } \\
\text { eredményesség növelése }\end{array}$ & $\begin{array}{l}\text { B Jelentós költség- } \\
\text { megtakarítási és nagyobb } \\
\text { hatékonysági elvárások }\end{array}$ \\
\hline $\begin{array}{l}\text { 3. HR-szolgáltatások } \\
\text { színvonalának emelése, } \\
\text { a munkatársak } \\
\text { ügyfélközpontú kezelése }\end{array}$ & $\begin{array}{l}\text { C HR-rendszerek } \\
\text { értékteremtésének növelése, } \\
\text { befektetett tóke jobb } \\
\text { megtérülése }\end{array}$ \\
\hline
\end{tabular}

Forrás: saját szerkesztés Bondarouk

és Graddick munkái alapján

Az 1. táblázat szemléletesen mutatja az e-HRMcélrendszer és a HRO okainak egybevágóságát: azaz a HRO mint egyfajta menedzsment-eszközrendszer illeszkedik az e-HRM célrendszeréhez. Mindemellett elemezve a Bondarouk-féle fogalmi keretet, logikai kapcsolatot találhatunk az e-HRM-célok és a HR-funkciók között is, amit a 2. ábra szemléltet (2. ábra).

$\mathrm{Az}$ 1. táblázat és a 2. ábra segítségével - ha figyelembe vesszük, hogy a megfelelő infokommunikációs technikák rendelkezésre állnak egy szervezetnél - a Greer által vázolt döntési helyzet áll elő: az automatizált feladatok nem tartoznak a szervezetek alapvetó kompetenciái közé, és ha más szervezetek, például erre szakosodott piaci szolgáltatók (vendorok) költséghatékonyabban végzik el ezt a feladatot, figyelembe véve a tranzakciós költségek elméletét, megnyílik az út a külsố szereplốk bevonására. Amennyiben egy szervezet esetében a HR-funkciókhoz a 2. ábrán szereplő célok kapcsolódnak, melyek egyben megegyeznek az 1. táblázatban ismertetett HR-outsourcing-kiváltó okokkal, létrejöhet a kihelyezés. Ennek az okozati kapcsolatnak az eredményeképpen magyarázható a Cedar-kutatásban ismertetett eredmény is: Ami standardizálható és az elektronikus, fóképp internetes megoldásokkal jól menedzselhetó, kiszervezéshez vezethet. 
A HRM-funkciók e-HRM-célok kapcsolata

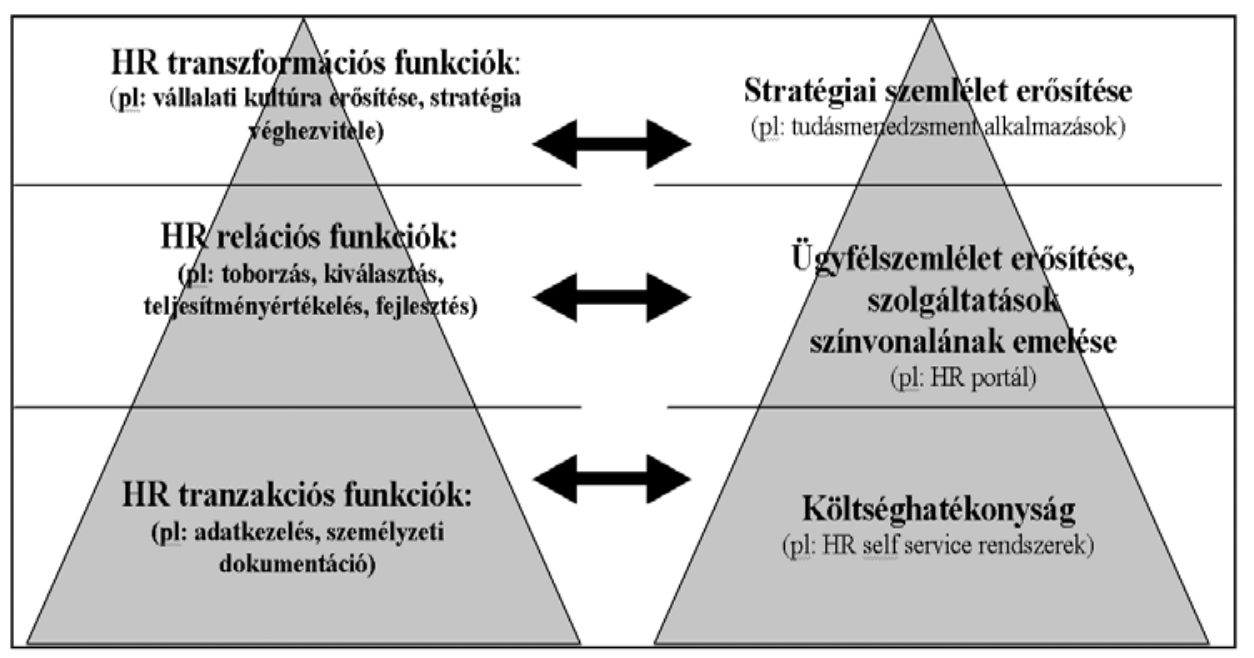

Forrás: saját szerkesztés Bondarouk Lepak ésés Wright munkái alapján

- A vizsgált vállalatoknál mind a három e-HRM-cél azonosítható volt: a célok között egyaránt szerepelt a költségcsökkentés, a munkatársak ügyfélközpontú kiszolgálása, valamint a HR-tevékenység stratégiai erôsítése. A kutatás egy negyedik tényezôt is azonosított a nemzetközi vállalatoknál: a HR-tevékenység standardizálását, a HR-eljárások és funkciók egységesítését globális szinten.

- A vizsgált vállalatoknál szakadék látható a funkcionálisan (informatikailag) rendelkezésre álló e-HRM-eszközök és a

\section{Esettanulmányok: az e-HRM és a HR outsourcing fogalomrendszerének empirikus vizsgálata}

\section{Kutatási elözmények}

Az e-HRM és a HR-outsourcing fogalomrendszerének vizsgálatára a SZTE GTK Üzleti Tudományok Intézetében 2000 óta folyó, többéves kutatási keretprogramban került sor. A komplex kutatási program célja, hogy feltárja az információs társadalom gazdaságának különböző aspektusait, különös tekintettel az e-business és az infokommunikációs technológia (IKT) jelenségvilágára. Ezen komplex kutatási program egyik ága a munka világában bekövetkezô változások feltáró elemzése. Az e-HRM és a HR-outsorcing empirikus vizsgálatának konkrét kutatás-módszertani előzménye az e-HRM-definíció kapcsán bemutatott holland kutatócsoport nagyvállalati e-HRMtevékenységét bemutató esettanulmány módszere. A Hollandiában elvégzett kvantitatív kutatásban megfigyelték a vállalatok alapvető elveit a humánerőforrás-tevékenység kapcsán, elemezték az e-HRM célokat, számba vették az e-HRM-fajtákat a szervezeteknél, és vizsgálták az elért eredményeket. A kutatás az IBM (számítástechnika), az ABN AMRO (bankszektor), a Dow Chemicals (vegyipar), a Ford (autógyártás), valamint a Belgacom (telekommunikáció) vállalatoknál zajlott, melyek a kilencvenes évék végén mind bevezettek valamilyen e-HRMrendszert.

A kutatási eredmények között a legfontosabbak a következók voltak (Bondarouk et al., 2004): mindennapi gyakorlatban használt eszközök között. Hiába rendelkeztek a vállalatok az e-HRM tranzakciós és transzformációs rendszerekkel, teljeskörúen csak operációs célokra használták (személyes adatok és információmenedzsment célokra) azokat. Az esettanulmányok alapján az operációs-tranzakciós-transzformációs rendszerek zárt hierarchiában állnak, azaz az operációs rendszer üzemeltetése előfeltétele a tranzakciósnak, a tranzakciós pedig elófeltétele a transzformációsnak.

- Az eredmények (kimenetek) vizsgálata kapcsán megállapítást nyert, hogy elsôsorban a költségcsökkentés, illetve a hatékonyságnövelés dedikálható, főleg az adminisztráció egyszerúsítése és a felhasználóorientált, önkiszolgáló (self-service) megoldások, valamint az online kommunikációs rendszerek miatt. Az elkötelezettség és a kompetencia növelése kapcsán látványos eredmények nem voltak tapasztalhatók.

- A vizsgálatok feltárták, hogy az e-HRM eszköztára az alsóvezetői szinten a vállalati harmonizáció, standardizáció és decentralizáció erôs eszközrendszerévé vált. Érdekes tény, hogy habár mind az öt vállalatnál jellemző módon „,minden sarkon” van egy PC, nem mindenki rendelkezett megfelelő hozzáféréssel és jártassággal. A globális HR-politika, az úgynevezett „,corporate policy” alkalmazásával kapcsolatban kiderült, hogy vannak olyan lokális, illetve nemzeti sajátosságok, amelyek erôsebbnek bizonyultak, mint a ,globális vállalati akarat”.

Jogosan adódik a kérdés, hogy a holland vizsgálat kutatási eredményei mennyiben feleltethetók meg a 
magyar vállalati gyakorlatnak? A holland vizsgálat módszertanát és eredményeit adaptálva Magyarországon is empirikus kutatásba kezdtünk, melynek operacionalizált célja az e-HRM és a HR-outsourcing jelenségvilágának feltárása, a holland eredményekkel történő összevetése.

\section{Kutatási koncepció}

Kutatási modellként a cikkben is bemutatott ciklikus szemléletet vettem alapul: a szervezet stratégiai céljaiból (1), a HR törekvésekból (2), az IT vállalaton belüli színvonalából (3) és az alkalmazott menedzsment-eszköztárból (4) származtatható az e-HRM eszközrendszere (5), mely a funkcionális HR-területeken keresztül (6) hat a kitúzött célok elérésére (7). Módszertani szempontból követve a holland esettanulmány módszerét, strukturált mélyinterjúk, kutatási jegyzókönyvvel zárt helyszíni látogatások adják az esettanulmányok gerincét, kiegészítve azokat szekunder információkkal (vállalat honlapján található információk, vállalati kiadványok, újságcikkek, sajtótájékoztatók anyaga). Jelen cikkben szereplő kvantitatív eredmények ezen esettanulmányokból származnak.

\section{Kutatási design}

A strukturált interjúk, a kutatási modellból adódóan több kérdésre keresték a választ, mely a modell fenti számozását alapul véve a következőképpen összegezhető:
- az általános stratégiai célok, a HR szerepe, jelentősége a szervezeten belül $(1,2)$,

- a HR implementációja e-HRM-eszközökkel a szervezetben $(3,4)$,

- felhasznált e-HRM-megoldások és HRO-a HR-funkciók kapcsán $(5,6)$,

- elért eredmények, megoldásra váró feladatok (7).

A kutatás során második lépésként a cégek kiválasztása történt meg, mely kapcsán az alábbi szempontrendszert vettem figyelembe:

- használjanak fejlett IT-technológiát az üzleti folyamataikban (A),

- különbözó iparágakból kerüljön ki mindegyik vizsgált szervezet (B),

- méretuik - dolgozói létszámukat tekintve - legyen különböző, de egyiknek se legyen kevesebb mint 500 fő (C),

- tulajdonosi struktúrájukat tekintve legyenek különbözốk (D).

Ennek alapján információszúrés módszerével a Flextronics, a Magyar Posta és a WizzAir került a figyelmem homlokterébe, mert a három szervezet különkülön és összefüggésében is megfelel a fenti elvárásoknak, melyet a 2. táblázat ábra szemléltet:

A cégek kiválasztási szempontrendszere és fontosabb paraméterei

\begin{tabular}{|c|c|c|c|c|}
\hline & Wizz Air & Flextronics & Magyar Posta & Összefüggések \\
\hline $\begin{array}{l}A \text { IT hasz- } \\
\text { nálat }\end{array}$ & $\begin{array}{l}\text { Ideáltipikus dotcom vállalat, } \\
\text { csak az interneten keresztül } \\
\text { értékesít, állásait honlapján } \\
\text { meghirdeti }\end{array}$ & $\begin{array}{l}\text { Multinacionális } \\
\text { standardoknak megfelelő } \\
\text { IT-használat }\end{array}$ & $\begin{array}{l}\text { Saját fejlesztésú magas, } \\
\text { biztonsági színvonalat } \\
\text { képviselő, zárt postai } \\
\text { rendszer }\end{array}$ & $\begin{array}{l}\text { Múködő weboldalak, } \\
\text { különböző fejlettségú } \\
\text { funkcionalitásokkal }\end{array}$ \\
\hline $\begin{array}{l}B \text { Iparág (te- } \\
\text { vékenységi } \\
\text { terület) }\end{array}$ & Légi közlekedés (Európán belül) & $\begin{array}{l}\text { Gyártás, összeszerelés, } \\
\text { logisztika }\end{array}$ & Közösségi szolgáltatás & $\begin{array}{l}\text { Egy szabályozott piac, } \\
\text { egy versenypiac és egy } \\
\text { monopolisztikus piaci } \\
\text { szereplő }\end{array}$ \\
\hline $\begin{array}{l}C \text { Méret } \\
\text { (dolgozói } \\
\text { létszám) }\end{array}$ & $\begin{array}{l}\text { Közel } 500 \text { fős munkavállalói } \\
\text { létszám }\end{array}$ & $\begin{array}{l}\text { Közel } 4000 \text { fős } \\
\text { munkavállalói létszám }\end{array}$ & $\begin{array}{l}\text { Közel } 36000 \text { fős } \\
\text { munkavállalói létszám }\end{array}$ & $\begin{array}{l}\text { Arányosan különböző } \\
\text { dolgozói létszám és más-más } \\
\text { nagyságrendú telephelyszám }\end{array}$ \\
\hline $\begin{array}{l}D \text { Tulajdono- } \\
\text { si struktúra }\end{array}$ & $\begin{array}{l}\text { Magyar magánszemélyek } \\
\text { alapították, jelenleg 50\%-os } \\
\text { európai, 50\%-os amerikai } \\
\text { tulajdoni hányad ismeretes } \\
\text { (jelenleg nincs a tózsdén) }\end{array}$ & $\begin{array}{l}\text { Nemzetközi, ázsiai } \\
\text { tulajdonosok }\end{array}$ & Állami tulajdon & $\begin{array}{l}\text { Teljesen eltéró tulajdonosi } \\
\text { struktúra }\end{array}$ \\
\hline $\begin{array}{l}E \text { Magyaror- } \\
\text { szági jelenlét }\end{array}$ & 2004-ben alakult & $\begin{array}{l}\text { 1997-tól } \\
\text { Magyarországon }\end{array}$ & $\begin{array}{l}\text { 1994-tôl rt formában, de } \\
\text { több száz éves múlttal }\end{array}$ & $\begin{array}{l}\text { Eltéró idóhorizont a } \\
\text { múködésben }\end{array}$ \\
\hline
\end{tabular}

Forrás: saját szerkesztés 
A 2. táblázat jól érzékelteti: három olyan vállalatról van szó, melyek az „A" szempontnak (fejlett IT-használat) egyformán megfelelnek, de a B, C, D, E szempontok szerint teljesen eltérő́ek. Ebbő́l adódóan alkalmasak arra, hogy feltárva az e-HRM gyakorlatukat - esettanulmány módszerével - betekintést kapjunk az e-HRM és a HR-outsourcing hazai kapcsolatrendszerébe.

Az esettanulmányokban szereplő 11 strukturált interjút és a helyszíni látogatásokat 2007 elsố negyedévében bonyolítottuk le. Jelen cikkben, részben terjedelmi korlátok, részben a fogalomrendszer érdemi szemléltetése érdekében, csak az e-HRM-megoldások és a HRO-alkalmazás szerepelnek a hollandiai eredményekkel összevetve, szem előtt tartva a tudományos kutatások nyilvánosságának elvét és az üzleti titkok védelmét.

\section{Kutatási eredmények}

A vizsgálatba vont mindhárom cég használ infokommunikációs technológáit a munkaszervezésben: a nagyvállalati gyakorlatnak megfelelően a munkahelyi kommunikáció alapvetố csatornája az intranet, azonban a vizsgált vállalatok internetes megjelenése jelentősen eltér egymástól.

A Flextronics belsố intranetportálján keresztül támogatja a munkaszervezést, mely a munkahelyi információáramlás elsődleges eszköze. A rendszerhez minden vonalbeli vezetố hozzáfér. Érdekes tény, hogy a vállalatnak nincs magyar nyelvú oldala, így online karrieroldala sem (ami megfelel az anyacég leányvállalatokra vonatkozó elő́rásainak).

A Magyar Posta „Investor in People” nemzetközi díjban részesült kiemelkedő HR-tevékenységének eredményeképpen. A Posta szintén intranetes megoldást fejlesztett ki a munkaszervezés támogatására, mely jelenleg elsősorban informatikai beruházási és üzemeltetési költségek miatt nem minden vonalbeli vezetô számára elérhetô. A Postának informatív weboldala van, de webes karrierrovatot nem tartalmaz.

A WizzAir megalakulása óta speciális, a légiközlekedést kiszolgáló elektronizált rendszeren keresztül végzi a munkaszervezést. A szervezet minden munkavállalójának elérést biztosít, és meg is követeli annak használatát: a munkatársak (jellemzően a légiszemélyzet) elektronikus csatornán keresztül kapják meg a konkrét idôszakra vonatkozó feladatát. A WizzAir honlapján karrierrovatot üzemeltet, a vizsgált időszakban 6 különböző állásajánlatra lehetett jelentkezni.

Összességében elmondható, hogy mindhárom szervezet használ informatikai eszközrendszert HR-folyamatai támogatásához. Habár különböző megoldásokat alkalmaznak, mindhárom szervezet esetében a HR-stratégia szerves része az elektronizáció, mely alapvetóen a HR-adminisztrációt érinti.

\section{e-HRM-célok megléte}

A vizsgált vállalatoknál - összhangban a holland kutatási eredményekkel - mindhárom e-HRM-cél azonosítható volt. A HR-költségek minimalizálása a WizzAir összvállalati stratégiájának része, ami egyben az üzleti modell alapja. A Magyar Posta esetében ez a törekvés a modernizáció része, a Flextronicsnál pedig elsôsorban a versenyképességból és a globális standardokhoz való igazodásból eredeztethető.

A munkatársak ügyfélközpontú kiszolgálása, valamit a HR-tevékenység stratégiai erősítése szintén mindhárom vállalat esetében napirenden van, azonban az elektronikus rendszerekhez történő hozzáférés minden munkatárs esetében csak a WizzAirnél teljes körú (ott egyben kötelezó is). A Flextronics, illetve a Magyar Posta esetében ezen rendszerek hatóköre a vonalbeli vezetôkig értelmezhetô, mivel a munkavállalóknak egyelőre nincs biztosítva a hozzáférés, és az interjúk tanúsága szerint a dolgozók digitális írástudása nem is tenné lehetôvé ezen megoldások használatát. Így a munkatársak ügyfélközpontú kiszolgálása elektronikus rendszerek segítségével csak bizonyos munkavállalók körében értelmezhetô, emiatt nem lehet teljes körú.

\section{e-HRM-eszközrendszer és \\ a HR-outsourcing}

A vizsgált vállalatok körében az elektronikus eszközrendszer alapvetôen a HR-tranzakciós funkciók területén, fóleg a HR-adminisztráció területén épült ki. Mindhárom szervezet automatizálta a juttatási rendszerét (bérszámfejtés), de megoldásaik különbözók. A Magyar Posta nagyvállalati ERP-megoldást használ juttatási rendszerének múködtetésére, melyet központilag menedzsel országos szinten. A Flextronics outsourcing partnert iktatott be ezen feladat ellátására magyar telephelyeinél. A WizzAir pedig nemzetközi szinten tevékenykedô outsourcing-szolgáltatót alkalmaz. Eltérés a holland kutatási eredményekkel kapcsolatban, hogy csak tervezés, esetleg bevezetés alatt van a HR-szoftverek beszerzése a különböző HR-funkciók támogatására (HR-relációs funkciók). A relációs funkciók támogatását jól mutatja a toborzás elektronikus támogatása. Mindhárom szervezet használ valamilyen infokommunikációs eszközrendszert ezen a területen (pl. e-mailben fogadják az önéletrajzokat), de mindhárom vizsgált szervezet fejlesztést tervez ebben a kérdésben. 


\section{e-HRM-eredmények}

Hasonlóan a holland kutatási eredményekhez, az itthoni esettanulmányokban is csak a hatékonyság növelése kapott hangsúlyt, az elkötelezettség vagy a kompetencia növelése nem szerepel az eredmények között. A kompetencia növelésével kapcsolatban ugyan mindhárom szervezet használ a vállalati képzések, tréningek nyilvántartására, dokumentációjára valamilyen informatikai megoldást, azonban ennek innovatív e-learning támogatása a vizsgált idôszakban nem valósult meg.

A vizsgálatba vont három vállalat abban is megegyezik, hogy ellentétben a holland kutatással, nem jellemzô az önkiszolgáló rendszerek (self-service) kiemelt fejlesztése, illetve ezzel kapcsolatos igények nem kerültek napirendre.

$\mathrm{Az}$ esettanulmányokból származó legfontosabb megállapításokat - a holland eredményekkel összevetve a 3. táblázat tartalmazza. menedzsmenttechnikaként, és ez alátámasztja a bevezetốben szereplő munkahipotézisem, miszerint az infokommunikációs technikák adaptálása, az e-HRM rendszer bevezetése egyben lehetôséget teremt a HRtevékenységek kiszervezésére.

Az e-HRM eszközrendszer vállalati alkalmazása kapcsán azt találtam, hogy habár számottevố különbségek vannak az operazionalizálás során, a célok és az eredmények azonosak, és egybevágóságot mutatnak a holland kutatási eredményekkel.

A cikkben nem vizsgáltam a kiinduló Harvard modell megfelelőségét, habár annak normatív szemléletmódja korlátozó lehet (lásd Kővári és Poór ez irányú összehasonlító munkáit), és a fogalmak meghatározása kapcsán sem törekedtem különböző iskolák álláspontjának bemutatására, mint például a Harvard modell szemléletétôl különböző Shrivastava modelljére sem tértem ki, mivel nem akartam teoretikus összehasonlítást ten-

3. táblázat

Az esettanulmányokból levonható legfontosabb megállapítások

\begin{tabular}{|l|l|l|l|}
\hline & \multicolumn{1}{|c|}{$\begin{array}{c}\text { Az esettanulmányokból levont } \\
\text { következtetések itthon }\end{array}$} & \multicolumn{1}{c|}{$\begin{array}{c}\text { Az esettanulmányokból levont } \\
\text { következtetések külföldön }\end{array}$} & $\begin{array}{c}\text { Egyezés/ } \\
\text { eltérés }\end{array}$ \\
\hline e-HRM-célok & $\begin{array}{l}\text { Domináns költségcsökkentés, } \\
\text { dedikálható belsó ügyfél és stratégiai } \\
\text { szemlélet }\end{array}$ & $\begin{array}{l}\text { Költségcsökkentés, } \\
\text { ügyfélközpontú belsó kiszolgálás, stratégiai } \\
\text { szemlélet erósítése }\end{array}$ & részben egyezó \\
\hline e-HRM-eszközrendszer & $\begin{array}{l}\text { Fókusz a HR-adminisztráción } \\
\text { és a tranzakciós rendszereken }\end{array}$ & Fókusz a HR-relációs rendszereken & eltéró \\
\hline HRO & Teret nyert az outsourcing & Teret nyert az outsourcing & egyezó \\
\hline e-HRM-eredmények & Nő́tt a hatékonyság & $\begin{array}{l}\text { Nótt a hatékonyság és az önkiszolgáló } \\
\text { rendszereken keresztül az összhang }\end{array}$ & részben egyezó \\
\hline
\end{tabular}

Forrás: saját szerkesztés

\section{Összegzés}

Az e-HRM és a HRO olyan új kifejezések az üzleti szótárakban, melyek tartalma jelenleg szigorúan véve nem egzakt módon definiált, jelenségvilága szerteágazó. Mint arra Szabó Katalin és Hámori Balázs is felhívja a figyelmünket az információs gazdaságról írt könyvükben az outsourcing fogalmának kapcsán: Mint annyi más új jelenségre, az outsourcingra sem alakult ki egységes definíció még a szakemberek körében sem.

Írásomban fogalmi keretet kívántam adni ennek a két rövidítésnek, ahol a fogalmakhoz tartozó célokat és az eszközrendszert is feltáró módon bemutattam. A fogalmak tisztázása kapcsán arra építettem, hogy az e-HRM tágabb értelemben illeszthetô a Harvard modellbe, és az e-HRM, valamint a HRO ugyanazon célokat szolgálja. Ennek következménye, hogy a HRO értelmezhetố az e-HRM célrendszert szolgáló ni. Az esettanulmányok módszere csak a tendenciák bemutatására alkalmas, az e-HRM és a HRO magyarországi kialakulása kapcsán. Mérhetô, statisztikailag is megfogható eredményekkel nem szolgál. Ezek a korlátok egyben a jövóbeni kutatási irányok között kijelölik a legfontosabbat is: az e-HRM és a HRO hatókörének pontosítását, mely egyrészt megmutathatja a HRO-piac nagyságát, másrészt azokat a HR-funkciókat, melyek kiszervezése egyre intenzívebbé válhat. Véleményem szerint ezek a „best practice” módszerével, valamint idősoros összehasonlító elemzésekkel pontosíthatók, kutathatók.

Mindezeken túl a cikkben bemutatott e-HRM és a HRO fogalomkört szemléltetô ábrák használhatók lehetnek az egyetemi oktatói munkában, és meglátásom szerint segíthetnek a magyarországi e-HRM-projektek megtervezése kapcsán, mindezzel közelebb kerülhetünk mint kutatók az e-business jelenségvilágának megértéséhez. 


\section{Felhasznált irodalom}

Ball, K. (2001): The use of Human Resource Information Systems: a survey. Personnel Review 6. pp. 677-693.

Beer, M. et all. (1984): Managing Human Assets. NewYork: Free Press.

Bondarouk, T. - Ruel, H. - Looise, J.K. ( 2004): E-HRM: Innovation or Irritation, Utrecht: Lemma Publishers

Cedar (2006). Workforce Technologies and Service Delivery Approaches Survey, Ninth Annual Edition [online] avaible on cedarcrestone.com

Cooke, F.L. - Shen, J. - Mcbride, A. (2005): Outsourcing $\mathrm{HR}$ as a competitive strategy? Human Resource Management. 44. pp. 413-422.

Davis, S. (2004): Itt a vég a HR számára? In: Effron et al.: HR a 21. században. Budapest. HVG Kiadó

Effron, M. - Candossy, R. - Goldsmith, M. (2004): HR a 21. században. Budapest: HVG Kiadó

Enyedi, I. (2003): Elektronikus módszerek és virtuális valóság a személyzeti munkában. Humánpolitikai Szemle, május, pp. 21-37.

Graddick, M. (2006): Élet a kiszervezés után: a tanulságok és a HR mint stratégiai üzleti partner. In: M. Losey, D. Ulrich, S. Meisinger: A HR jövője: az emberieróforrás menedzsment perspektívái. Budapest: HVG Kiadó

Greer-Youngblood-Gray(1999):Human resource management outsourcing: The make or buy decision. Academy of Management Executive Vol. 13 No.3, pp. 85-92.

Henneman, T. (2005): Measuring the True Benefit of Human Resources Outsourcing. Workforce Management. July. pp. 76-77.

Keebler, T. (2001): HR outsourcing in the internet area. in Walker, A.J. ed: Web-based Human resources. NewYork: McGrow-Hill

Korponay, Á. (2002): Álláskeresési trendek a világon, Európában és Magyarországon. Munkaügyi Szemle, július - augusztus, pp. 10-12.

Kovach, K. - Hhughes, A. - Fagan, P. - Maggitti, P. (2002): Administrative and strategic advantages of HRIS. Employment Relations Today. 10. pp. 1002-1039.
Lepak, D. - Snell, S. (1998): Virtual HR: strategic human resource management in the $21 \mathrm{st}$ century. Human Resource Management Review. 3. pp. 215-234.

Lepak, D. - Bartol, K. - Erhardt, N. (2005): A contingency framework for the delivery of HR practices. Human Resource Management Review 15. pp. 139-159.

Miller, J. (2003): High Tech and High Performance: Managing Appraisal in the Information Age. Journal of Labour Research. 3. pp. 409-424.

Poór, J. (2006): HR mozgásban: Nemzetköziesedés az emberi eróforrás menedzsmentben. Budapest: MMPC

Poór, J. (2001): Emberierőforrás-menedzsment rendszerek múködésének alapjai. Munkaügy Szemle, szeptember pp. 15-19.

Reddington, M. - Martin, G. (2006): Theorizing the link between e-HR and strategic HRM. Conference Proceedings, First e-HRM Conference. Twente, University of Twente

Roberts, Z. (2001): Outsourcing and e-HR will expand. Peple Management. Oct. 25 pp. 10.

Ruta, C. (2005): The aplication of change management theory to HR portal inplementation. Human resource management. 1. pp. 35-53.

Shrivastava, S. - Shaw, J. B. (2004): Liberating HR trough technology. Human Resource Management. 42. pp.: 201-222.

Szabó, K. - Hámori, B. (2006): Információgazdaság. Budapest: Akadémiai Kiadó

Tóthné S. G., - Majó Z. (2003): Infokommunikációs technikák térhódítása az online munkaerópiacon és a humán eróforrás-menedzsment területén. Munkaügyi Szemle, december, pp. 31-36.

Turnbull, J. (2002): Inside Outsourcing. People Management: Connected HR pp. 10-11.

Watsonwyatt. (2005): HR Outsourcing: Finding the Optimal Mix - HR Technology Trends Survey [online] avaible on watsonwyatt.com

Wright, P. - Dyer, L. (2000): People in the Business. Working paper 00-11. Ithaca: Center for Advanced Human Resource Studies, Cornell University 